\author{
Ivana Kanceljak, PhD, Assistant Professor \\ University of Zagreb, Faculty of Law \\ Trg Republike Hrvatske 14, Zagreb, Croatia \\ ivana.kanceljak@pravo.hr
}

\title{
REFORM OF CONSUMER SALES LAW OF GOODS AND ASSOCIATED GUARANTEES - POSSIBLE IMPACT ON CROATIAN PRIVATE LAW
}

\begin{abstract}
This paper discusses novelties proposed in a new Sales Law Directive Proposal. Firstly, explanation is given regarding the main reasons for the reform and how the higher level of consumer protection in sales contracts could be achieved. It has been noticed that the European legislator was focused on four important questions: the time frame for the burden of proof, notification on lack of conformity, the hierarchy of goods and the legal guarantee period. All these new solutions would be given through a new maximum harmonization directive which would appeal Directive 1999/44/EC on certain aspects of the sale of consumer goods and associated guarantees. Although the sales law reform is still in the legislative process phase, it was possible to discuss how the novelties would affect Croatian private law.
\end{abstract}

Keywords: sales law reform, Directive 1999/44/EC, Proposal of Sales Law Directive, consumer protection, lack of conformity

\section{INTRODUCTION}

Although the free movement of goods, persons, services and capital on the Single Market already exists, the European Commission has seen that its full potential still has not been achieved. Among other reasons, it was an inspiration to a Digital Single Market Strategy for Europe published in May 2015. ${ }^{1}$ One of the legislations which meant to be its legal base was introduced by the European Commission on 31 October 2017 under the name "Amended proposal for a Directive of the European Parliament and of the Council on certain aspects concerning contracts for the sales of goods amending Regulation (EC) No 2006/2004 of

\footnotetext{
1 European Commission: Communication from the Commission to the European Parliament, the Council, the European Economic and Social Committee and the Committee of the Regions: A Digital Single Market Strategy for Europe, Brussels, 6.5.2015, COM (2015) 192 final, available at: http://eur-lex.europa.eu/legal-content/EN/TXT/PDF/?uri=CELEX:52015DC0192\&from=EN] Accessed 07 February 2018
} 
the European Parliament and of the Council and Directive 2009/22/EC of the European Parliament and of the Council and repealing Directive 1999/44/EC of the European Parliament and of the Council (hereinafter: The Sales Law Directive Proposal)". ${ }^{2}$ The first part of the article would point out the reasons for amendments to the first Sales Law Directive Proposal, main purposes and its possible impact on consumer rights.

Since it has already been seen what is the main focus of the Sales Law reform, it is possible to discuss the impacts on Croatian Private Law but with reservations since this reform is still in a proposal phase. Directive 1999/44/EC of the European Parliament and of the Council of 25 May 1999 on certain aspects of the sale of consumer goods and associated guarantees (hereinafter: Directive 1999/44/EC) ${ }^{3}$ is already transposed into the Obligations Act (hereinafter: $\mathrm{OA})^{4}$. Having in mind that this directive was a minimum harmonisation directive, it has to be discussed whether the transposition of a new directive would ensure better protection of consumer's rights or not. Also, the question is whether it will be possible to keep, with or without changes in Croatian Private Law special solutions introduced through the extended harmonisation for protection of traders as buyers and for their protection in all contracts with consideration.

\section{WHY IS A REFORM OF CONSUMER SALES LAW AND GUARANTEES REQUIRED?}

\subsection{Steps between the Directive 1999/44/EC and the Sales Law Directive Proposal}

A Digital Single Market is meant to be built on three pillars. They would be: "better access for consumers and businesses to online goods and services across $\mathrm{Eu}-$ rope, creating the right conditions for digital networks and services to flourish and maximising the growth potential of European Digital Economy". ${ }^{5}$ To accomplish

2 Amended proposal for a Directive of the European Parliament and of the Council on certain aspects concerning contracts for the sales of goods amending Regulation (EC) No 2006/2004 of the European Parliament and of the Council and Directive 2009/22/EC of the European Parliament and of the Council and repealing Directive 1999/44/EC of the European Parliament and of the Council, Brussels, 31.10.2017., COM/2017/0637 final - 2015/0288 (COD), available at:

http://eur-lex.europa.eu/legal-content/EN/ALL/?uri=COM:2017:0637:FIN] Accessed 07 February 2018

3 Directive 1999/44/EC of the European Parliament and of the Council of 25 May 1999 on certain aspects of the sale of consumer goods and associated guarantees, Official Journal L 171, 07/07/1999 P. $0012-0016$

4 Obligations Act, Narodne novine 35/05, 41/08, 125/11, 78/15

5 Digital Single Market Strategy, op. cit. note 1, p. 3 and 4 
these objectives European Commission already started with legislative activities in December 2015 by proposing a Directive of the European Parliament and of the Council on certain aspects concerning contracts for the online and other distance sales of goods (hereinafter: The First Proposal of the Sales Law Directive). ${ }^{6}$ It was stated that the scope of this proposal were "certain requirements concerning distance sales contracts concluded between the seller and the consumer, in particular rules on conformity of goods, remedies in case of non-conformity and the modalities for the exercise of these remedies".?

The first proposal emphasized the benefits of cross-border online and other distance sale of goods. It has been noticed that 39\% of businesses selling online only sell in their own country. ${ }^{8}$ Also, according to the European Commission statistical information, only $18 \%$ of the consumers in the European Union buy online from traders from other Member State countries, while in Croatia only $12 \%$ of them do. ${ }^{9}$ This showed that there are barriers that influence on consumers confidentiality to shop online cross-border which is directly in relation with consumers' uncertainty about their contractual rights. ${ }^{10}$ This results in a fact that buying in their own country limits consumers from more competitive prices and wider choice of goods. ${ }^{11}$

6 Proposal for a directive of the European and of the Council on certain aspects concerning contracts for the online and other distance sales of goods, Brussels, 9.12.2015, COM (2015) 635 final, 2015/0288(COD), available at

[http://eur-lex.europa.eu/legal-content/EN/TXT/?uri=COM\%3A2015\%3A635\%3AFIN] Accessed 07 February 2018; Also see: Commission staff working document - Impact assessment: Accompanying the document Proposals for Directives of the European Parliament and of the Council (1) on certain aspects concerning contracts for the supply of digital content and (2) on certain aspects concerning contracts for the online and other distance sales of goods, Brussels, 9.12.2015, SWD(2015) 274 final, available at:

'https://ec.europa.eu/transparency/regdoc/rep/10102/2015/EN/SWD-2015-274-F1-EN-MAINPART-1.PDF] Accessed 07 February 2018

7 As it was also stated in art. 1 of the first proposal of the directive that from application would have been exempted distance contracts for the provision of services and any durable medium incorporating digital content where the durable medium has been used exclusively as a carrier for the supply of the digital content to the consumer.

8 The first proposal of the Sales Law Directive, op. cit. note 6, p. 2

9 European Commission brochure: "Jedinstveno digitalno tržište - stranica pojedinačne države", available at [https://ec.europa.eu/commission/sites/beta-political/files/croatia_hr.pdf] Accessed 07 February 2018

10 See more: The first proposal of the Sales Law Directive, op. cit. note 6, page 2, 3

11 See: Rafael, M. R., The Directive proposals on Online sales and Supply of Digital Content (Part 1): will the new rules attain their objective of reducing legal complexity?. Revista de Internet,Derecho y Politica, IDP No. 23, December 2016, available at:

[https://idp.uoc.edu/articles/10.7238/idp.v0i22.3082/galley/3200/download/] Accessed 07 February 2018 
Consumers' rights in sale contracts have already been in member states harmonized by transposition of the Directive 1999/44/EC. ${ }^{12}$ This directive provided consumers with a minimum level of protection through regulation of rights in case of nonconformity with sale contract, possible remedies and guarantees. Minimum harmonization approach influenced the new differences of regulation of sales law between member states, which caused new barriers ${ }^{13}$ and seems to be one of the main obstacles for proper functioning of online sale of consumer goods. ${ }^{14}$ This was taken as the main argument for the preparation and content of the first proposal of the Sales Law Directive. The main changes proposed through the First proposal of the Sales Law Directive aimed to achieve maximum harmonization and proper functioning of the e-commerce as a crucial element of the Digital Single Market. ${ }^{15}$

As it was already stated, the European Commission published the amended proposal of the Sales Law Directive in October 2017. Two main reasons for amendments could be found in different documents given through discussion with the Council and preparatory bodies but also in "Results of the Fitness Check of consumer and marketing law and of the evaluation of the Consumer Rights Directive (hereinafter: Fitness Check Report)" 16 from May 2017, which are taken into account through possible impacts of fully harmonized rules on contracts for the sale of goods. ${ }^{17}$

12 The first proposal was not the first attempt of the sales law reform after Directive 1999/44/EC. European Commission published in 2011 a proposal for a Regulation on a Common European Sales Law - CESL (Brussels, 11.10.2011., COM (2011) 635 final, 2011/0284, COD) but it was withdrawn

13 For example, traders have to adapt to different obligations which arise for them from other member states regulations which causes even more costs. See: The first directive proposal, op. cit. note 6, p. 5

14 See more: The first proposal of the Sales Law Directive, op. cit. note 6, p. 3, 4; Schulte-Nölke, H., Twigg-Flesner, C., Ebers, M., EC Consumer Law Compendium - The Consumer Acquis and its transposition in the Member State. Sellier, European Law Publishers, 2008, pp. $407-$ 471

15 See more on the content of the first proposal: The first proposal of the Sales Law Directive, op. cit., note 6, p. 17-31

16 Results of the Fitness Check of consumer and marketing law and of the evaluation of the Consumer Rights Directive, available at:

'http://ec.europa.eu/newsroom/just/item-detail.cfm?item_id=59332] Accessed 08 February 2018

17 Commission staff working document on the Impacts of fully harmonised rules on contracts for the sales of goods supplementing the impact assessment accompanying the proposal for a Directive of the European Parliament and of the Council on certain aspects concerning contracts for the online and other distance sales of goods Accompanying the document Amended proposal for a Directive of the European Parliment and of the Council on certain aspects concerning contracts for the sales of goods, amending Regulation (EC) N 2006/2004 of the European Parliament and of the Council and Directive 2009/22/EC of the European Parliament and of the Council and repealing Directive 1999/44/EC of the European Parliament and of the Council, SWD/2017/0354 final - 2015/0288 (COD), available at: 


\subsection{Fitness Check and Directive 1999/44/EC as an impact on the amend- ed proposal of the Sales Law Directive}

Directive 1999/44/EC was, among some other consumer protection directives, one of the main focuses of the Fitness Check Report. Part of this report is a "Study on the costs and benefits of minimum harmonisation ${ }^{18}$ under the Consumer Sales and Guarantees Directive 1999/44/EC and of potential full harmonisation and alignment of EU rules for different sales channels"19 (hereinafter: Study on Directive 1999/44/EC). The main objective of the Study on Directive 1999/44/ EC were possible consequences of full harmonization of consumer sales law and guarantees which are discussed through benefits and costs having in mind possible impact of this kind of harmonization on different sales channels (both online and offline). Study on Directive 1999/44/EC was mostly focused on four elements already harmonized which are the obligation to notify the seller of a defect within the certain period of time, the hierarchy of remedies, the reversal of the burden of proof and the legal guarantee period. ${ }^{20}$

Directive 1999/44/EC regulates in art. 5. p. 2. that "Member States may provide that, in order to benefit from his rights, the consumer must inform the seller of the lack of conformity within a period of two months from the date on which he detected such lack of conformity". Study on Directive 1999/44/EC has shown that in seven Member States such obligation does not exist. ${ }^{21}{ }^{22}$ It has been pointed out that not having obligation of notification could have benefits such as lower number of disputes, especially disputes about the exact time when the consumer discovered the defect, but could also lower the burden which is put on consumers,

'http://eur-lex.europa.eu/legal-content/EN/TXT/?uri=CELEX:52017SC0354] Accessed 12 February 2018

18 See more on harmonization: Josipović, T., Izazovi harmonizacije gradanskog prava putem direktiva. in: Civil Law Forum for South East Europe Collection of studies and analyses, First Regional Conference, Cavtat 2010 - Volume I; Beograd, 2010, pp. 291-306

19 European Commission: Study on the costs and benefits of minimum harmonisation under the Consumer Sales and Guarantees Directive 1999/44/EC and of potential full harmonisation and alignment of EU rules for different sales channels, March 2017, available at:

[ec.europa.eu/newsroom/document.cfm?doc_id=44638] Accessed 14 February 2018

20 Study on Directive 1999/44/EC, op. cit. note 19, p. 19

21 Study on Directive 1999/44/EC, op. cit. note 19, p. 30

22 Possibility to choose between regulation of notification or an option not to have one in the process of transposition of Directive 1999/44EC, was in academia argued with a fact that "for consumers shopping abroad, this can be a dangerous trap", which came true. See: Magnus, U., Consumer sales and associated guarantees. in: Twigg-Flesner, C (ed.), The Cambridge Companion to European Union Private Law, Cambridge University Press, Cambridge, 2010, p. 254 
which increases overall consumer protection. ${ }^{23}$ But on the other side, it might lead to the abuse of consumer right. ${ }^{24}$

Article 3, p. 2 of the Directive 1999/44/EC regulates that "in the case of a lack of conformity, the consumer shall be entitled to have the goods brought into conformity free of charge by repair or replacement, or to have an appropriate reduction made in the price or the contract rescinded with regard to those goods". Also, it states that "in the first place, the consumer may require the seller to repair the goods or he may require the seller to replace them, in either case free of charge, unless this is impossible or disproportionate (art. 3, p. 3 Directive 1999/44/EC). Study on Directive 1999/44/EC has pointed out that five Member States, including Croatia, have chosen to provide a consumer with a free choice of remedies, but in two Member States consumers have the right to directly reject a product within 30 days from the purchase. ${ }^{25}$ The study furtherly discussed a free choice of remedies along with the right to reject. According to given opinions, it seems that a short period of time for a rejection could increase competition and product quality but also that a free choice of remedies is better for the on-line cross-border trade. ${ }^{26} \mathrm{On}$ the other hand it was noticed that a free choice of remedies might lead to a dispute between consumers and traders. ${ }^{27}$

Timeframe for reversal of burden of proof is regulated in art. 5, p. 3 of the Directive 1999/44/EC in a way that "unless proved otherwise, any lack of conformity which becomes apparent within six months of delivery of the goods shall be presumed to have existed at the time of delivery unless this presumption is incompatible with the nature of the goods or the nature of the lack of conformity". At the moment there are three Member States with a longer time period for reversal of burden of proof. ${ }^{28}$ It has been suggested that a longer period could give consumers a higher chance of obtaining an effective remedy or even quality or durability of the product. ${ }^{29}$ Having in mind the traders, it is possible that such change could cause additional costs. ${ }^{30}$

\footnotetext{
23 Study on Directive 1999/44/EC, op. cit. note 19, p. 30, 31

24 See more on that aspect: Study on Directive 1999/44/EC, op. cit. note 19, p. 31, 32

25 Study on Directive 1999/44/EC, op. cit. note 19, p. 21, 22, 34

26 Study on Directive 1999/44/EC, op. cit. note 19, p. 34

27 Study on Directive 1999/44/EC, op. cit. note 19, p. 34, 35

28 Study on Directive 1999/44/EC, op. cit. note 19, p. 27. Also see more on national court decisions: Patti, F. P., The Effectiveness of Consumer Protection in Sales Contracts - Some Observations from Recent European Case Law, Journal of European Consumer and Market Law, issue 5, 2015, p. 183

29 See more: Study on Directive 1999/44/EC, op. cit. note 19, p. 27.28

30 See more along with figure 5 in Study on Directive 1999/44/EC, op. cit. note 19, p. 29
} 
The fourth important topic of the Study on Directive 1999/44/EC was on legal guarantee period. Directive 1999/44/EC regulates liability of seller where the lack of conformity becomes apparent within two years as from delivery of the goods according to art. 5, p. 1. In the same article is stated that "if, under national legislation, the rights laid down in art. 3,p. 2 are subject to a limitation period, that period shall not expire within a period of two years from the time of delivery". At the moment, only five countries have either longer limitation period or there is not a fixed time limit. ${ }^{31}$ "Increasing the possibility of obtaining redress when a product is faulty" ${ }^{\prime 2}$ was pointed out as a benefit of a longer period. From the aspect of costs it was discussed that it may lead to higher consumers' goods prices. ${ }^{33}$ It can be concluded that absence of notification and a longer period both for legal guarantee and in case of timeframe for reversal of burden of proof could, along with the regulation of hierarchy of remedies, mean benefits to consumers. Study on Directive 1999/44/EC has shown many of them. Some of them concern consumers personally such as their confidence and overall better protection but they also affect them indirectly through better quality and longer durability of products.

\subsection{CONSUMER SALES LAW DIRECTIVE PROPOSAL - CURRENT MAIN FOCUSES OF THE REFORM OF THE SALES LAW}

\subsubsection{General remarks}

Reform of the consumer sales of goods law proposed by The Sales Law Directive Proposal would through its implementation effect private systems of sales law of all Member States. Repealing of the Directive 1999/44/EC could be taken as a crucial change imposed by the reform. Also, this proposal is considered to be a supplement to existing consumer protection given by Directive 2011/83/EU of the European Parliament and of the Council of 25 October 2011 on consumer rights. ${ }^{34}$

31 Study on Directive 1999/44/EC, op. cit. note 19, p. 20-22

32 Study on Directive 1999/44/EC, op. cit. note 19, p. 22

33 See more on costs: Study on Directive 1999/44/EC, op. cit. note 19, p. 26, 27

34 Directive 2011/83/EU of the European Parliament and of the Council of 25 October 2011 on consumer rights amending Council Directive 93/13/EEC and Directive 1999/44/EC of the European Parliament and of the Council and repealing Council Directive 85/577/EEC and Directive 97/7/EC of the European Parliament and of the Council, OJ L 304, 22.11.2011, p.64. See more on connection between The Sales Law Directive Proposal and other legal sources: The Sales Law Directive Proposal, op. cit. note 9 , p. 5 
Solutions of The Sales Law Directive Proposal were the result of already explained differences between consumer protection regulation between Member States caused by implementation of a Directive 1999/44/EC which was a minimum protection directive. Since it was clear that existence of the minimum protection still has not prevailed differences and eliminated cross border sales barriers, it was not a surprise that a new reform is based on a maximum and targeted harmonization directive. The Sales Law Directive Proposal clearly states that "Member States shall not maintain or introduce provisions diverging from those laid down in this Directive including more or less stringent provisions to ensure a different level of consumer protection" (art. 3 of the second proposal). ${ }^{35}$

Maximum harmonization approach and reform of only online cross border sales law according to the first directive proposal of Sales Law Directive also was not considered as an appropriate way of reform. It was considered with a reason that such approach would lead to a new fragmentation of sales law regulation and consumer protection because it will lead to a higher level of protection of consumers in online cross border sales than in face-to-face sale. ${ }^{36}$ The Sales Law Directive Proposal was necessary to ensure the same level of consumer protection both for online and offline sales of goods.

\subsubsection{The scope of application and subject matter of the Sales Law Directive Proposal}

As it was already briefly stated, the purpose of this directive would be the harmonization of sale of goods in order to establish functional internal digital market. This special regulation proposal focuses on a specific contract, contract of sales with explicitly determined subjects ${ }^{37}$ who conclude these contracts concerning particular objects.

The Sales Law Directive Proposal sets out rules for sales contracts between traders and consumers regardless of whether the contract is concluded online or "face to face". Furthermore, it defines sales contract as "any contract under which the seller transfers or undertakes to transfer the ownership of goods, including goods which are to be manufactured or produced, to the consumer and the consumer

\footnotetext{
35 The same level of harmonization with a different scope was introduced in the first proposal. See a discussion on that in: Havu, K., The EU Digital Single Market from a Consumer Standpoint: How Do Promises Meet Means. Contemporary Readings in Law and Social Justice 9(2), 2017, p. 156

36 The Sales Law Directive Proposal, op. cit. note 2, p. 9

37 See definitions of terms consumer, trader and producer in art. 2. of the Sales Law Directive Proposal, op. cit. note 2
} 
pays or undertakes to pay the price thereof" (art. 2. (a) of the Sales Law Directive proposal). ${ }^{38}$

The proposed directive does not regulate all aspects and effects of sales contract. It focuses only on areas which are shown as barriers to normal functioning of internal digital market. That is the reason why the rules set out in the directive proposal are focused on conformity of goods, remedies in case of non-conformity and the modalities for the exercise of these remedies (art. 1, p. 1 of the Sales Law Directive Proposal). On the other hand it doesn't provide rules on pre-contractual information requirements, the right of withdrawal for distance contracts and delivery conditions have already been fully harmonised. ${ }^{39}$ It is explicitly stated that "this Directive shall not affect national general contract laws such as rules on formation, the validity or effects of contracts, including the consequences of the termination of a contract" (art. 1 p. 5 of the Sales Law Directive Proposal).

It is proposed that new directive would not apply on contracts for the provision of services ${ }^{40}$ and to any durable tangible medium incorporating digital content where the durable tangible medium has been used exclusively as a carrier for the supply of the digital content to the consumer (for example CD or DVD, art. 1, p. 2 and 3 of the Sales Law Directive Proposal). It means that the directive would apply only to sale of tangible movable items, but also to one "where the digital content is embedded in such a way that its functions are subordinate to the main functionalities of the goods and it operates as an integral part of the goods" (for example toys and household appliances with integrated digital content). ${ }^{41}$ Movable tangible items sold by way of execution or otherwise by authority of law, and as well water, gas and electricity unless they are put up for sale in a limited volume or a set quantity, would not be covered by this directive (art. 2 (e) of the Sales Law Directive Proposal).

Having in mind those particular goods as objects of sales contract it has to be added that each Member State can decide whether consumer protection will exist or not in cases of second-hand goods sale at public auctions (art. 1, p. 4 of The Sales Law Directive Proposal).

38 Compare with art. 1 of Directive 1999/94/EC. On this see more: Rafael, R. M., Intercambios digitales en Europa: La propuestas de Directiva sobre compraventa en linea y suministro de contenidos digitales. Revista CESCO de Derecho de Consumo, No 17/2016, p. 18

39 See more introduction of the directive, the Sales Law Directive Proposal, op. cit. note 2, p. 12

40 It might apply in cases of sale contracts providing both for the sale of goods and the provision of services but then only to the part relating to the sale of goods (see art. 1. p. 2. of the Sales Law Directive Proposal, op. cit. note 2). This is the same approach given by Directive 2011/83/EU, op. cit., note 34

${ }^{41}$ See more introduction of the directive, the Sales Law Directive Proposal, op. cit. note 2, p. 14 


\subsubsection{Conformity of goods}

Proposing solution for conformity of goods, the European legislator had in mind both material and legal ${ }^{42}$ defects. To assure consumers protection and their expectations, it combines objective and subjective criteria to specify when conformity of goods exists.

The seller has to ensure that the goods are in line with the contract and / or precontractual statement regarding "quantity, quality and description required by the contract, which includes that where the seller shows a sample or a model to the consumer the goods shall possess the quality of and correspond to the description of this sample or model (art. 4, p. 1 of The Sales Law Directive Proposal)". Also, in consideration of subjective consumer expectations, goods should be "fit for any particular purpose for which the consumer requires them and which the consumer made known to the seller at the time of the conclusion of the contract and which the seller has accepted (art. 4. p. 1 The Sales Law Directive Proposal)". 43 Art. 5 of the Sales Law Directive proposal provides special rules on requirements for conformity of the goods. ${ }^{44}$ Bearing in mind that there are some goods which require installation made by consumer before using goods directive proposal sets out further rules on possible lack of conformity which might result from an incorrect installation of the goods. ${ }^{45}$

Special provision with important novelty could be noticed in proposing solution for regulation of relevant time for establishing conformity with the contract. Liability of the seller for the lack of conformity would exist if such lack existed in two different moments in time. Firstly, it would be at the moment of acquisition of the physical possession of the goods by consumer or a third party indicated by

42 See the Sales Law Directive Proposal on third party rights proposed, op. cit. note 2, art. 7

43 See more: introduction of the directive, the Sales Law Directive Proposal, op. cit. note 2, p. 14, and Rafael, op. cit. note 38, p. 21, 22

44 The goods shall, where relevant: be fit for all the purposes for which goods of the same description would ordinarily be used, be delivered along with such accessories including packaging, installation instructions or other instructions as the consumer may expect to receive and possess qualities and performance capabilities which are normal in goods of the same type and which the consumer may expect given the nature of the goods and taking into account any public statement made by or on behalf of the seller or other persons in earlier links of the chain of transactions, including the producer (art. 5 of the Sales Law Directive Proposal, op. cit. note 2). This would apply unless seller shows that he was not, and could not reasonably have been aware of the statement in question, either by the time of conclusion of the contract the statement had been corrected or the decision to buy the goods could not have been influenced by the statement

45 See art. 6. of the Sales Law Directive Proposal (op. cit. note 2) on incorrect installation. For interpretation of consumers position it might be useful to remind on European Union Court of Justice judgment of 16 June 2011, C-65/09, Gebr. Weber GmbH v Jürgen Wittmer (C-65/09) and Ingrid Putz v Medianess Electronics GmbH (C-87/09), ECLI:EU:C:2011:396 
the consumer ${ }^{46}$ or secondly, when the carrier chosen by the consumer gains possession of the goods. Higher level of consumer protection is meant to be achieved through longer timeframe for reversal of burden of proof. ${ }^{47}$ It is presumed that any lack of conformity existed in above mentioned moments in time in case it becomes apparent within two years from the time the consumer or carrier gained possession of the goods. ${ }^{48}$ Reasons for this time frame extension could be found in European legislator aspiration to achieve impact on production of consumer goods in order to achieve better quality of consumer goods or even better control of goods imported from non-Member States. ${ }^{49}$ Possible negative aspect could not be easily set aside. One can argue that having such a long period might acquire a better determination of possible lack of conformity. It could be achieved for example through exclusion of consequences of usual use of goods. Another novelty of the reform of sales law is the absence of obligation of consumers to notify the seller of existence of any lack of conformity. ${ }^{50}$

\subsubsection{Consumer's remedies}

In case of the lack of conformity with the contract, consumers would have the same rights as under Directive 1999/44/EC but the way of invoking the rights would be changed. ${ }^{51}$ The Sales Law Directive proposal has introduced hierarchy of the remedies which can be considered as an important novelty for achieving removal of barriers on Internal Market. Remedies can be realized in a time limit of two years. ${ }^{52}$

46 See more on a case where the goods were installed by the seller or under the seller's responsibility in art. 8. p. 2. od the Sales Law Directive Proposal, op. cit. note 2

47 More on timeframe for reversal of burden of proof in this article under 2.2. Fitness Check and Directive 1999/44/EC as an impact on the amended proposal

48 See art. 8.p. 3. of the Sales Law Directive Proposal, op. cit. note 2. In comparison to Directive 1999/44/ EC (art. 2. p. 5) under which the timeframe was only 6 months which means that now it would be much longer. See also: Rafael, op. cit. note 39, p. 28

49 See: introduction of the directive, the Sales Law Directive Proposal, op. cit. note 2, p. 15 and Study on Directive 1999/44/EC, op. cit. note 3, p. 27. 28. along with this article under 2.2. Fitness Check and Directive 1999/44/EC as an impact on the amended proposal

50 See: introduction of the directive, the Sales Law Directive Proposal, op. cit. note 2, p. 15., this article under 2.2. Fitness Check and Directive 1999/44/EC as an impact on the amended proposal and Rafael, op. cit. note 39, p. 28. On contrary, which is in line with authors opinion that such obligation should exist see: Kröll, S., Mistelis, L., Viscasillas P. P., UN-Convention on the International Sales of Goods (CISG), 1. Auflage 2011, CISG art. 39 (www.beck-online, accessed on: 01 March 2018); Rn 7-9

51 See more under this article under 2.2. Fitness Check and Directive 1999/44/EC as an impact on the amended proposal

52 See art. 14. of the Sales Law Directive Proposal along with introduction of the directive proposal, $o p$. cit. note 2, p. 16 
In order to preserve existing contractual relationship, the first two main remedies from which consumer might choose would be both equally right to replacement and right to repair, all free of charge for the consumer ${ }^{33}$ (according to art. 9. p. 1. along with art. 10. and 11.of the Sales Law Directive Proposal).${ }^{54} \mathrm{As}$ an addition to the first remedies, "a repair or replacement shall be completed within a reasonable time and without any significant inconvenience to the consumer, taking account of the nature of the goods and the purpose for which the consumer required the goods (art. 9. p. 2. of the Sales Law Directive Proposal)".

The next step in choosing the remedies can be taken if a repair or replacement are impossible or unlawful, if the seller has not completed repair or replacement within a reasonable time, when a repair or replacement would cause significant inconvenience to the consumer or when the seller has declared, or it is equally clear from the circumstances, that the seller will not bring the goods in conformity with the contract within a reasonable time (according to art. 9. p. 3 of the Sales Law Directive Proposal). In such situations consumer would have a right to a proportionate reduction ${ }^{55}$ of the price or to terminate the contract.

European legislator has chosen a more detailed approach on regulation of termination of the contract then in Directive 1999/44/EC. First of all, if the consumer chose to terminate the contract he would be obliged to notify the seller. In cases where the lack of conformity with the contract relates only to some of the goods, consumer will be entitled to terminate the contract only in relation to those goods and any other goods which the consumer acquired as an accessory to the nonconforming goods (art. 9. p. 2. of the Sales Law Directive Proposal). Regardless of whether the termination relates to a part of the contract or to the entire contract, the Sales Law Directive Proposal provides detailed legal effect of termination. ${ }^{56}$

If consumer would use his right to terminate the contract the seller will have an obligation to "reimburse to the consumer the price paid without undue delay and in any event not later than 14 days from receipt of the notice and shall bear the cost of the reimbursement (art. 13. p. 3 of the Sales Law Directive Proposal)". On

53 To be clear on consumers position it was additionally regulated that "The consumer shall not be liable to pay for any use made of the replaced goods in the period prior to the replacement (art. 10. p. 3. of the Sales Law Directive Proposal, $o p$. cit. note 2)

54 Special rule on consumer's choice between repair and replacement can be found in art. 11. of the Sales Law Directive Proposal, op. cit. note 2

55 See more art. 12. of the Sales Law Directive Proposal, op. cit. note 2

56 It has to be reminded that the Directive 1999/44/EC didn't regulate details on effect of termination which usually lead to the application of rules which already existed on legal effect of termination of contract. In authors opinion, implementation of this rule might in some Member States lead to indirect change of the position of consumers 
the other hand, the consumer will be obligated "to return, at the seller's expense, to the seller the goods without undue delay and in any event not later than 14 days from sending the notice of termination (art. 13. p. 3 of the Sales Law Directive Proposal)". "Where the goods cannot be returned because of destruction or loss, the consumer shall pay to the seller the monetary value which the non-conforming goods would have had at the date when the return was to be made, if they had been kept by the consumer without destruction or loss until that date, unless the destruction or loss has been caused by a lack of conformity of the goods with the contract (art. 13. p. 3 of the Sales Law Directive Proposal)". ${ }^{57}$ Also it is proposed that the consumer will pay for a decrease in the value of the goods only to the extent that the decrease in value exceeds depreciation through regular use but that the payment for decrease in value will not exceed the price paid for the goods. ${ }^{58}$

The Sales Law Directive Proposal does not say anything about the right to damages in cases when the damage was made on other consumer's things beside bought goods. ${ }^{59}$ Although it does not directly propose solution for damages on the bought goods it can be said that the consumer will have to satisfy with adequate price reduction or new or replaced product. Also, in comparison to Directive 1999/44/ EC new Sales Law Directive Proposal does not restrict remedies in case of minor material defect which means that a consumer may terminate a contract in such cases. ${ }^{6061}$

\subsubsection{Guarantees}

The last crucial area of the reform could be found in rules of the Sales Law Directive Proposal on commercial guarantees. To remove the barriers which have been noticed and provide transparency in consumer protection rights it is necessary through maximum harmonization to introduce special rules for commercial guarantees.

$57 \quad$ If the European legislator has decided to keep the notification of seller about the existence of any lack of conformity that exact day might have been taken as a day for determination of the value of the goods

58 See art. 13. p. 3. of the Sales Law Directive Proposal, op. cit. note 2

59 See more: Zoll, F., The Remedies in the Proposals of the Online Sales Directive and the Directive on the Supply of Digital Content. Journal of European Consumer and Market Law, Volume 5, Issue 6, 2016., p. 252

60 See: introduction of the Sales Law Directive Proposal, op. cit. note 2 p. 16 and art. 3. p. 6. of Directive 1999/44/EC, op. cit. note 3

${ }_{61}$ Maybe such approach could prevent in future cases already seen in judgement of the European Court of Justice, C-32/12, Soledad Duarte Hueros v Autociba SA and Automóviles Citroën España SA, ECLI:EU:C:2013:637 
The Sales Law Directive Proposal sets out three possible ways of giving statement on the guarantees or gaining information on the guarantees. Consumer could be informed on guarantees during pre-contractual phase, through advertisement or the guarantee statement. If there are any differences between them, seller would be bind to those guarantee statement which is the best for the consumer. ${ }^{62}$

According to Sales Law Directive Proposal it will be expected from Member States to implement rules on a form of the guarantee statement. The directive proposal sets out that "the guarantee statement shall be made available on a durable medium and drafted in plain, intelligible language (art. 15. p. 2 of the Sales Law Directive Proposal)". ${ }^{63}$ Additionally it has to be noted that the Sales Law Directive Proposal similarly to the Directive 1999/94/EC also sets a rule for the content of the guarantee in art. 15. p. 2. On the other hand, the Sales Law Directive Proposal allows Member States to provide additional rules on other aspects concerning commercial guarantees as long as those rules do not reduce the protection set out in directive proposal (art. 15. p. 5 of the Sales Law Directive Proposal).

Proposing new solutions for approximation of laws concerning the guarantees, the European legislator did not take into account another possible solution already seen as a way of achieving maximum level of consumer protection. It could be argued that guarantees should be given to every consumer in every Member Sate in the same form and with the same effect, and maybe with the same content. This could be possible through standardized guarantees (information) form. ${ }^{64}$

\section{POSSIBLE IMPACT OF SALES LAW DIRECTIVE PROPOSAL ON CROATIAN PRIVATE LAW}

\subsection{Transposition of the directive in general}

Directives could be transposed in private national laws in order to prevail barriers between Member States, to achieve functioning of the Internal Market and consumer protection. For that purposes, Directive 1999/44/EC has been implement-

62 See art. 15. p.1 of the Sales Law Directive Proposal, op. cit. note 2

63 See more about this in art. 15. p. 2 and p. 3. of the Sales Law Directive Proposal, op. cit. note 2

64 Standardized information forms aren't something new, they are already well known in consumer protection law. See for example Directive 2008/122/EC of the European Parliament and of the Council of 14 January 2009 on the protection of consumers in respect of certain aspects of timeshare, longterm holiday product, resale and exchange contracts, Official Journal of the European Union, L 33, 03 February 2009 and Directive 2014/17/EU of the European Parliament and of the Council of 4 February 2014 on credit agreements for consumers relating to residential immovable property and amending Directives 2008/48/EC and 2013/36/EU and Regulation (EU) No 1093/2010 Text with EEA relevance, Official Journal of the European Union, L 060, 28 February 2014 
ed in Croatian private law through new OA which came into the force on January the $1^{\text {st }} 2006^{65}$ but also through additional changes of the OA in $2008^{66}$ which have provided complete transposition of the Directive 1999/44/EC. Aims of the Directive 1999/44/EC are achieved through art. $400-429$ of the OA on liability for material defects and $430-437$ of the OA on liability for the legal defects. ${ }^{67}$

Although the main idea of the Directive 1999/44/EC was consumer protection, the Croatian legislator has decided to implement this directive as a general rule ${ }^{68}$ (art. $357 \mathrm{OA})^{69}$ which led to an extended harmonization. Firstly, the transposed rules are applicable to all contracts with consideration and secondly they apply not only to trader-consumer relation (B2C) but also to all other situations such as relations between traders $(\mathrm{B} 2 \mathrm{~B})$ and between consumers $(\mathrm{C} 2 \mathrm{C}) .{ }^{70}$ This means that rules on the lack of conformity apply to all relations except in those segments where the $\mathrm{OA}$ regulated explicitly otherwise for $\mathrm{B} 2 \mathrm{~B}^{71}$ relations or $\mathrm{B} 2 \mathrm{C}^{72}$ relations.

Usually when a new directive is transposed in the national law the question where it should be implemented arises. In case of Sales Law Directive Proposal, it is questionable should it be transposed in a completely new regulation, in the Consumer Protection Act since it aims to protect consumer or in the OA as Directive 1999/44/EC already is. The first two should not even be considered because new regulation would lead to a new fragmentation of the private law and the second

65 Obligations Act, Narodne novine, 35/05

66 Obligations Act, Narodne novine, 41/08

67 See more: Gorenc, V. et al., Komentar zakona o obveznim odnosima. Narodne novine, Zagreb, 2014, p. 681-734; Klarić, P., Vedriš, M., Građansko pravo, Narodne novine, Zagreb, 2014, p. 414 - 426; Petrić, S., Odgovornost za materijalne nedostatke stvari prema novom Zakonu o obveznim odnosima. Zbornik Pravnog fakulteta Sveučilišta u Rijeci, Vol. 27., No. 1. ožujak 2006., pp. 87 -127

68 Baretić, M., Prava kupca u slučaju materijalnih i pravnih nedostataka na prodanoj stvari, Aktualnosti hrvatskog zakonodavstva i pravne prakse. 22, 2015, p. 25., Ernst, H., Odgovornost za materijalne nedostatke. in: Nuni, A. et al. (ed.), Forum za građansko pravo za jugoistočnu Evropu: Knjiga II, GTZ, Skopje, 2012, p. 333

69 Article 357 of OA regulates:

(1) In case of a contract with consideration each contracting party is liable for material defects in its performance.

2) Each contracting party is also liable for legal defects in its performance and it is obliged to protect the other contracting party from any third party rights and claims that might eliminate or reduce the rights of the other contracting party.

(3) The provisions of this law relating to the liability of the seller for material and legal defects in its performance shall apply accordingly to the obligations of the transferor, unless otherwise provided for certain cases.

70 See definitions of these relations: art. 402. p. 3. OA, art. 14. p. 2. OA. See also: Baretić, op. cit. note 68 , p. 31-36

71 For example, see: art. 403. p. 1. OA, art. 404. p. 1-3 OA, art. 406. p. 1. OA

72 For example, see: art. 402. p. 3. of the OA, art. 403. p. 4. of the OA, art. 408. p. 2. OA 
would create two legal ways of protection in case of material and legal defect, one for consumers and one for the others which has already been seen by the Croatian legislator ${ }^{73}$ as a non-acceptable solution through the implementation of Directive 1999/44/EC. The Sales Law Directive Proposal, under condition that it becomes a directive, since it aims to change already transposed directive should be transposed in OA through the changes of existing rules for the liability of the seller for material and legal defects. Having in mind that the Sales Law Directive Proposal aims for maximum protection of consumers, the Croatian legislator will not have many options for deviation except for possible special provisions for consumer and nonconsumer contracts. Some of the main goals of the reform of the sales law will be furthermore discussed from the aspect of possible change of Croatian legislation.

\subsubsection{Liability for material and legal defects of performance as a general rule}

If the legislator choses the option of changing existing rules of the liability of the seller for material and legal defects in OA, the first and main question in process of the transposition of the Sales Law Directive Proposal will be the existence and content of the above mentioned general rule set out in art. 357 of the OA. It can be argued that a general rule in art. 357 of the OA should be kept but maybe with additional changes. The Sales Law Directive Proposal excludes service contract and contracts for the supply of digital content. ${ }^{74}$

The first question is whether art. 357 of the OA should exclude application of responsibility for lack of conformity in case of service contracts. Service contracts are not in Croatian law regulated explicitly as a special contract. Rules on lack of conformity would apply to all contracts with consideration including services contract no matter who are the contracting subjects. On the other hand, in case of service contracts, consumers are protected by rules of the Consumer Protection Act (hereinafter: CPA) ${ }^{75}$ which are in line with Directive 2011/83/EU but it has to be mentioned that there are not any special rules on lack of conformity for service contracts. It could be said that choosing an option not to explicitly exclude service contracts should not be taken as a deviation from the Sales Law Directive.

Much more important question will be the exclusion of contracts for the supply of digital content. This solution of the Croatian legislator will depend of the fact whether another directive now also in phase of proposal - Proposal for a Directive

\footnotetext{
73 This was not only the opinion of Croatian legislator, see more: Schulte-Nölke, Twigg-Flesner, Ebers, op. cit. note 14, pp. 407-471

74 See more in this article: 2.3 .2. The scope of application and subject matter of the Sales Law Directive Proposal.

75 Consumer Protection Act, Narodne novine, 41/14, 110/15
} 
of the European Parliament and the Council on certain aspects concerning contracts for the supply of digital content ${ }^{76}$ - will be transposed or not at the moment of transposition of the Sales Law Directive Proposal. That is of high importance since both directives regulate lack of conformity - one for goods and the other for digital content. It is still unknown how the Directive on Digital Content will be implemented, will it be possible to implement this directive along with changes of existing regulation for material and legal defect or our Croatian legislator will decide on a specific regulation of a contract for the supply of digital content along with solution for lack of conformity. All those questions are still open for a discussion in another research paper.

If Directive on digital content will not yet be implemented at the moment of transposition of the Sales Law Directive, then art. 357 OA will have to exclude the application for consumer contracts for the supply of digital content since the Sales Law Directive Proposal is not applicable to such contracts. On the other hand, if the Directive on certain aspects concerning contracts for the supply of digital content will be already implemented, then the content of art. 357 OA will depend on the manner of transposition of that directive which without further research cannot be predicted in this article. Having in mind both of the directives it could be argued that if it will be possible due to the deadlines for the implementation of both directives, it would be a good solution to propose their transposition through balanced changes of $\mathrm{OA}$ at the same time.

\subsubsection{Timeframe for reversal of burden of proof}

It can be stated that the most important change of the OA might result from obligation to implement a longer timeframe for reversal of burden of proof from six months to two years. ${ }^{77}$ This would clearly affect art. 400 p. 3 of the OA, which now regulates this presumption.

New solution will clearly contribute to a better protection of Croatian consumers but it is questionable if such protection is needed in all relations especially in relations between traders. It can be discussed whether this imbalance between contracting parties which aims to protect the weaker party - consumer - should also exist between traders. The main reason for longer timeframe of burden of proof is

\footnotetext{
76 Proposal for a Directive of the European Parliament and the Council on certain aspects concerning contracts for the supply of digital content, $\operatorname{COM}(2015) 634$ final, 2015/0287(COD), hereinafter: Directive on digital content, Brussels, 9.12.2015, available at: http://eur-lex.europa.eu/legal-content/EN/TXT/HTML/?uri=CELEX:52015PC0634\&from=HR] Accessed 18 March 2018

77 See more in this article under: 2.3.3. Conformity of goods
} 
to make it even easier for the consumers. This means that consumers do not have to prove the existence of a material defect thanks to a presumption that it actually existed at the time when consumer for example acquired the physical possession of the goods. This is relevant under condition that the defect became apparent within two years. On the other hand, the trader could try to prove that the material defect did not exist at that time. Position of the trader while proving the existence of the material defect is not the same as the position of the consumer. European Union Court of Justice has in case C-497/13, Faber explained "that relaxation of the burden of proof in favour of the consumer is based on the determination that where the lack of conformity becomes apparent only subsequent to the time of delivery of the goods, it is 'well-nigh impossible for consumers' to prove that that lack of conformity existed at the time of delivery, whereas it is generally far easier for the professional to demonstrate that the lack of conformity was not present at the time of delivery and that it resulted, for example, from improper handling by the consumer". ${ }^{78}$ On the other hand, not only that traders as professionals could easily prove that the lack of conformity doesn't exist, they could easily prove that the lack of conformity exists.

This all leads to a conclusion that the same presumption which is in favour of the consumer should not be in favour of traders in relationships between traders. It can be argued that the presumption should exist in favour of trader in relation between traders, but that should be kept as it is -with the timeframe of six months.

\subsubsection{Notification of lack of conformity}

Higher level of consumer protection is aimed to be achieved by absence of notification of lack of conformity. ${ }^{79}$ For Croatian consumers such obligation exists in case of both visible and hidden material defects (art. 403 and $404 \mathrm{OA}){ }^{80}$ The same obligation, but under different conditions, exists in relations between traders. This sales law reform might be a good opportunity to discuss changes concerning trader's obligation of notification in $\mathrm{B} 2 \mathrm{~B}$ relations.

\footnotetext{
78 See judgment of the European Court of Justice of 4 June 2015, C-497/13, Froukje Faber v Autobedrijf Hazet Ochten BV, ECLI:EU:C:2015:357, p. 54

79 See more in this article under: 2.3.3. Conformity of goods

80 For comparison of abovementioned articles see Croatian legislation before transposition of OA: art. 481 and 482 of Obligations Act from 1978, Official Journal SFRJ 29/1978, 39/1985, 46/1985, 57/1989, Narodne novine 53/1991, 73/1991, 3/1994, 111/1993, 107/1995, 7/1996, 91/1996, 112/1999, 88/2001, 35/2005 (hereinafter: OA 1978). More on this obligation see: Baretić, op. cit. note 68 , p. $42-45$
} 
It can be argued that obligation of notification in relations between traders, as in relations between consumers and traders should not exist. The research has already shown that there are many Member States that have decided during the implementation of Directive 1999/44/EC not to obligate buyer to notify seller about the material defect. ${ }^{81}$ For example, such obligation doesn't exist in German Civil Code both for consumers and traders as buyers which was explained by the fact that such an obligation has never existed in German Sales Law. ${ }^{82}$ It can be reminded that Croatian Sales Law has exactly the opposite regulation even since the OA 1978. But also, such long period has through the practice of the Croatian Courts ${ }^{83}$ shown that the lack of notification in a particular way or within a certain time frame or even a lack of acceptable proof of notification caused loss of traders' rights in many cases.

It has to be reminded that the Study on Directive 1999/44/EC has shown some negative aspects of the absence of notification even in $\mathrm{B} 2 \mathrm{C}$ relations. For example, German business association is concerned that "having no notification obligation can lead to situations where consumers could keep using a product and ask for remedies for a defect which was partly caused or worsened by using it". ${ }^{84}$ Also, the European business association ${ }^{85}$ argued that such approach leads to costs and losses for sellers. If sellers are notified in time, there is a higher possibility to repair goods or even in case of replacement to sell repaired goods as second-hand goods. All those problems might be even bigger in B2B relations, especially having in mind possible higher value of the goods.

Another argument might be taken into account. It can be argued that the care in the course of performing obligations and exercising rights is not the same for traders as it is for consumers. In obligations higher level of care is expected from traders. ${ }^{86}$ Besides that, it is expected from the parties in obligational relations to act in line with the principle of good faith (art. 4 OA). It can be said that the prin-

${ }_{81}$ Schulte-Nölke, Twigg-Flesner, Ebers, op. cit. note 14, p. 432. See also more in this article: 2.2. Fitness Check and Directive 1999/44/EC as an impact on the amended proposal

82 Rott, P., German Sales Law Two Years after the Implementation of Directive 1999/44/EC. German Law Journal, Issue 3, March, 2004, p. 251

83 See for example: Judgement of Higher Commercial Court, 23.01.2007., Pž 8224/04-3; Judgement of Higher Commercial Court, 23.10.2008., Pž 2223/06-5; Judgement of Higher Commercial Court, 01.06.2016., Pž 4584/2012-2; Judgement of Higher Commercial Court, 18.01.2017., PŽ 804/04-4; Judgement of Higher Commercial Court, 16.05.2006., Pž 7419/03-3

84 Study on Directive 1999/44/EC, op. cit. note 19, p. 31

85 Study on Directive 1999/44/EC, op. cit. note 19, p. 31. and 32

86 See: Gorenc, et. al., op. cit. note 67, p. 23, 24; art. 10. p. 1. OA and art. 5. p. 19 CPA which regulates term "professional care" 
ciple of good faith also requires from the trader as buyer to notify the other party on lack of conformity.

Either our legislator in implementation of the Sales Law Directive stays consistent with legal tradition of notification or it could propose a change. Reforming Croatian Sales Law by completely omitting obligation of notification in B2B relations might be seen too radical.

\subsubsection{Right to terminate the contract}

Consumer's rights in case of material defect would be according to the Sales Law Directive Proposal precisely put in order through hierarchy between them. ${ }^{87}$ This will probably lead to a change of art. 410 and art. 419 of the OA. The right to terminate the contract would be the last remedy for buyers (art. 13. of the Sales Law Directive Proposal). Although the intention of the European legislator was not to interfere with the legal effects of the termination of contract in national law, implementing this right through change of art. 419 of the OA will evidently affect the existing solution in Croatian national law regulated in art. 368 of the OA. ${ }^{88}$ The main rule in case of termination of the contract is that after termination of the contract both parties are released from their obligations except the obligation to pay damages (art. 386. p. 1 OA). Each party has a right to restitution if parties have fully or partially preformed their obligations (art. 386. p. 2 OA). When it comes to termination generally, art. 368 of the OA would apply but this will not be the case if the contract is terminated because of the lack of conformity New and changed article on effects of termination of contract in case of lack of conformity would have precedence over general rule set in art. 386 of the OA. This does not mean that art. 386 of the OA would be excluded.

Comparing existing article on effects of termination and the solution proposed in the Sales Law Directive Proposal the following can be concluded. Firstly, the proposed solution could be considered wider in scope than art. 368 OA while it will regulate more specifically deadlines for returning of what is already received. Secondly, art. 368 p. 4 of the OA could be, on the other hand, considered wider in the scope because it obligates buyer to "compensate for the benefits that it enjoyed in the meantime from whatever it is obligated to return or compensate" ${ }^{89}$ Application of this rule wouldn't be against the aims of the Sales

\footnotetext{
$87 \quad$ See more this article under: 2.3.4. Consumer's remedies

88 The Sales Law Directive Proposal sees this effect as general and side effect of termination, see proposal introduction, op. cit. note 2, p. 16, along with. art. 1. p. 5

89 Application of this rule would also be in line with interpretation of the European Court of Justice stated in judgement of 17 April 2008, C-404/06, Quelle AG v Bundesverband der Verbraucherzentralen
} 
Law Directive Proposal since it clearly states that any unreasonable enrichment of consumer should be prevented. ${ }^{90}$

Reform of the right to terminate the contract will in Croatian law bring to another important novelty, a new rule opposite to one already existing in art. 410 p. 3 of the OA. In situation where lack of conformity is minor, buyer is not entitled to terminate the contract but he is entitled to all other rights (art. 410 p. 3. of the OA). If there will not be any further change of the Sales Law Directive Proposal, Croatian buyers would be able to terminate the contract even in cases of minor conformity. ${ }^{91}$

\section{CONCLUSION}

With no doubt, the Sales Law Directive Proposal would achieve higher level of consumer protection, which will be an important step for the functioning of the Digital Single Market. At this phase of legislation procedure, the most important changes are a longer period of the burden of proof in favour of consumers, hierarchy between consumer's rights, detailed regulation of legal effect of termination of the contract, possible termination of the contract in case of a minor material defect and an absence of notification on material defect. For now, all thes solutions would be introduced through a maximum harmonization directive.

It is expected that new changes would influence legal certainty of consumer's rights, rise of their confidentiality to buy from sellers in other Member States along with a better access to a wide range of goods and overall decrease the number of disputes between traders and consumers. It is possible to argue that imbalance of the relation between traders and consumers, which exists to protect consumers as a weaker party, could have some negative effects. On the one hand, the idea is to encourage the cross border trade and to secure its growth, but on the other hand, if all proposed solutions stay as they are they might burden traders and even producers and importers, which could lead to higher prices of consumer's goods.

Along with other Member States, Croatian legislator will be faced with new changes of legislation, primarily the OA, in order to implement new sales law directive. Transposition could be conducted through changes of rules on lack of conformity,

und Verbraucherverbände, ECLI:EU:C:2008:231

90 This is primarily intended to achieve through already mentioned art. 13., p. 3 (d) od the Sales Law Directive proposal, op. cit. note 2, p. 16, see more in this article under: 2.3.4. Consumer's remedies. Application of these two solutions might lead to a situation that buyer will have to pay compensation for the use of the use of goods and one for a decrease in the value of the goods

91 See more this article under: 2.3.4. Consumer's remedies and the introduction of the Sales Law Directive Proposal, op. cit. note 2, p. 16 
which exists as seller's obligation along with art. 357 of the OA which sets rules on lack of conformity as a general institute of obligations law. This research has shown that possible change of art. 357 of the OA will depend on the moment of transposition of Directive on certain aspects concerning contracts for the supply of digital content since the Sales Law Directive proposal excludes digital content from its scope. The most difficult task for the Croatian legislator will be whether to apply consumers's rights even for traders, which act as buyers in B2B relations, or not. This question especially arises when it comes to a longer period of burden of proof and an obligation to notify the seller on the lack of conformity.

\section{REFERENCES}

\section{BOOKS AND ARTICLES}

1. Baretić, M., Prava kupca u slučaju materijalnih i pravnih nedostataka na prodanoj stvari, Aktualnosti hrvatskog zakonodavstva i pravne prakse. 22, 2015, pp. 25-56

2. Ernst, H., Odgovornost za materijalne nedostatke. in: Nuni, A. et al. (ed.): Forum za građansko pravo za jugoistočnu Evropu: Knjiga II, GTZ, Skopje, 2012, 333-346

3. Gorenc, V. et al., Komentar zakona o obveznim odnosima. Narodne novine, Zagreb, 2014, p. 681-734

4. Klarić, P., Vedriš, M., Građansko pravo, Narodne novine, Zagreb, 2014

5. Havu, K., The EU Digital Single Market from a Consumer Standpoint: How Do Promises Meet Means. Contemporary Readings in Law and Social Justice 9(2), 2017, pp. 146-183

6. Josipović, T., Izazovi harmonizacije gradanskog prava putem direktiva. in: Civil Law Forum for South East Europe Collection of studies and analyses, First Regional Conference, Cavtat 2010 - Volume I; Beograd, 2010, pp. 291-306

7. Kröll, S., Mistelis, L., Viscasillas P. P., UN-Convention on the International Sales of Goods (CISG), 1. Auflage 2011, (www.beck-online)

8. Magnus, U., Consumer sales and associated guarantees. in: Twigg-Flesner, C. (ed.), The Cambridge Companion to European Union Private Law, Cambridge University Press, Cambridge, 2010, pp. 243-256

9. Patti, F. P., The Effectiveness of Consumer Protection in Sales Contracts - Some Observations from Recent European Case Law, Journal of European Consumer and Market Law, issue 5, 2015., pp. 179-184

10. Petrić, S., Odgovornost za materijalne nedostatke stvari prema novom Zakonu o obveznim odnosima. Zbornik Pravnog fakulteta Sveučilišta u Rijeci, Vol. 27., No. 1. Ožujak 2006., pp. $87-127$

11. Rafael, M. R., The Directive proposals on Online sales and Supply of Digital Content (Part 1): will the new rules attain their objective of reducing legal complexity?. Revista de Internet,Derecho y Politica, IDP No. 23, December 2016 
12. Rafael, R. M., Intercambios digitales en Europa: La propuestas de Directiva sobre compraventa en linea y suministro de contenidos digitales. Revista CESCO de Derecho de Consumo, No 17/2016, pp. 11-44

13. Rott, P., German Sales Law Two Years after the Implementation of Directive 1999/44/EC. German Law Journal, Issue 3, March, 2004, pp. 237 - 256

14. Schulte-Nölke, H., Twigg-Flesner, C., Ebers, M., EC Consumer Law Compendium - The Consumer Acquis and its transposition in the Member State. Sellier, European Law Publishers, 2008

15. Zoll, F., The Remedies in the Proposals of the Online Sales Directive and the Directive on the Supply of Digital Content. Journal of European Consumer and Market Law, Volume 5, Issue 6, 2016, pp. 250-254

\section{COURT OF JUSTICE OF THE EUROPEAN UNION}

1. Case C-404/06, Quelle AG v Bundesverband der Verbraucherzentralen und Verbraucherverbände, ECLI:EU:C:2008:231

2. Case C-65/09, Gebr. Weber GmbH v Jürgen Wittmer (C-65/09) and Ingrid Putz v Medianess Electronics GmbH (C-87/09), ECLI:EU:C:2011:396

3. Case C-32/12, Soledad Duarte Hueros v Autociba SA and Automóviles Citroën España SA, ECLI:EU:C:2013:637

4. Case C-497/13, Froukje Faber v Autobedrijf Hazet Ochten BV, ECLI:EU:C:2015:357

\section{EU LAW}

1. Amended proposal for a Directive of the European Parliament and of the Council on certain aspects concerning contracts for the sales of goods amending Regulation (EC) No 2006/2004 of the European Parliament and of the Council and Directive 2009/22/EC of the European Parliament and of the Council and repealing Directive 1999/44/EC of the European Parliament and of the Council, Brussels, 31.10.2017., COM/2017/0637 final 2015/0288 (COD)

2. Commission staff working document - Impact assessment: Accompanying the document Proposals for Directives of the European Parliament and of the Council (1) on certain aspects concerning contracts for the supply of digital content and (2) on certain aspects concerning contracts for the online and other distance sales of goods, Brussels, 9.12.2015, SWD (2015) 274 final

3. Commission staff working document on the Impacts of fully harmonised rules on contracts for the sales of goods supplementing the impact assessment accompanying the proposal for a Directive of the European Parliament and of the Council on certain aspects concerning contracts for the online and other distance sales of goods Accompanying the document Amended proposal for a Directive of the European Parliment and of the Council on certain aspects concerning contracts for the sales of goods, amending Regulation (EC) №2006/2004 of the European Parliament and of the Council and Directive 2009/22/EC of the European Parliament and of the Council and repealing Directive 1999/44/EC of the European Parliament and of the Council, SWD/2017/0354 final - 2015/0288 (COD) 
4. Communication from the Commission to the European Parliament, the Council, the European Economic and Social Committee and the Committee of the Regions: A Digital Single Market Strategy for Europe, Brussels, 6.5.2015, COM (2015) 192

5. Directive 1999/44/EC of the European Parliament and of the Council of 25 May 1999 on certain aspects of the sale of consumer goods and associated guarantees, Official Journal $\mathrm{L}$ 171, 07/07/1999 P. $0012-0016$

6. Directive 2011/83/EU of the European Parliament and of the Council of 25 October 2011 on consumer rights amending Council Directive 93/13/EEC and Directive 1999/44/EC of the European Parliament and of the Council and repealing Council Directive 85/577/ EEC and Directive 97/7/EC of the European Parliament and of the Council, OJ L 304, 22.11.2011

7. Directive 2008/122/EC of the European Parliament and of the Council of 14 January 2009 on the protection of consumers in respect of certain aspects of timeshare, long-term holiday product, resale and exchange contracts, Official Journal of the European Union, L 33, 03 February 2009

8. Directive 2014/17/EU of the European Parliament and of the Council of 4 February 2014 on credit agreements for consumers relating to residential immovable property and amending Directives 2008/48/EC and 2013/36/EU and Regulation (EU) No 1093/2010 Text with EEA relevance, Official Journal of the European Union, L 060, 28 February 2014

9. Proposal for a directive of the European and of the Council on certain aspects concerning contracts for the online and other distance sales of goods, Brussels, 9.12.2015, COM (2015) 635 final, 2015/0288(COD)

10. Proposal for a Regulation on a Common European Sales Law - CESL (Brussels, 11.10.2011., COM (2011) 635 final, 2011/0284, COD

11. Proposal for a Directive of the European Parliament and the Council on certain aspects concerning contracts for the supply of digital content, COM(2015) 634 final, 2015/0287(COD)

\section{LIST OF NATIONAL REGULATIONS, ACTS AND COURT DECISIONS}

1. Obligations Act, Narodne novine 35/05, 41/08, 125/11, 78/15

2. Consumer Protection Act, Narodne novine, 41/14, 110/15

3. Obligations Act from 1978, Official Journal SFRJ 29/1978, 39/1985, 46/1985, 57/1989, Narodne novine 53/1991, 73/1991, 3/1994, 111/1993, 107/1995, 7/1996, 91/1996, 112/1999, 88/2001, 35/2005

4. Judgement of Higher Commercial Court, 16.05.2006., Pž 7419/03-3

5. Judgement of Higher Commercial Court, 23.01.2007., Pž 8224/04-3

6. Judgement of Higher Commercial Court, 23.10.2008., Pž 2223/06-5

7. Judgement of Higher Commercial Court, 01.06.2016., Pž 4584/2012-2

8. Judgement of Higher Commercial Court, 18.01.2017., PŽ 804/04-4 


\section{WEBSITE REFERENCES}

1. European Commission brochure: "Jedinstveno digitalno tržište - stranica pojedinačne države", available at:

[https://ec.europa.eu/commission/sites/beta-political/files/croatia_hr.pdf] Accessed 07 February 2018

2. European Commission: Study on the costs and benefits of minimum harmonisation under the Consumer Sales and Guarantees Directive 1999/44/EC and of potential full harmonisation and alignment of EU rules for different sales channels, March 2017, available at: [ec.europa.eu/newsroom/document.cfm?doc_id=44638] Accessed 07 February 2018

3. Results of the Fitness Check of consumer and marketing law and of the evaluation of the Consumer Rights Directive, available at

[http://ec.europa.eu/newsroom/just/item-detail.cfm?item_id=59332] Accessed 07 February 2018 